\title{
O erotismo impresso e a sexualidade feminina
}

\author{
Patricia Ferreira Cardoso
}

Rafael Mario Iorio Filho²

\begin{abstract}
Resumo:
O presente artigo destaca a evolução do erotismo impresso, desde a antiguidade, até o advento da indústria gráfica. Aborda a influência da publicidade nos textos e imagens para a modificação de crenças, valores e atitudes que interferem de forma negativa na sexualidade. Busca discutir o papel informativo e formativo das revistas femininas referente à sexualidade.
\end{abstract}

\section{Palavras chave:}

erotismo impresso, revistas femininas, sexualidade

\begin{abstract}
:
This paper highlights the evolution of print eroticism, from antiquity, to the advent of the printing industry. It addresses the influence of advertising in texts and images for changing beliefs, values and attitudes that negatively interfere with sexuality. It seeks to discuss the informative and formative role of women's magazines regarding sexuality.
\end{abstract}

\section{Keywords:}

print eroticism, feminine magazines, sexuality

\section{Introdução}

Nas civilizações antigas observa-se claramente a natureza erótica do ser humano. Na Mitologia Grega encontramos nos feitos dos deuses e heróis um misto de beleza, força física e sensualidade. Zeus, um grande sedutor de ninfas e mulheres mortais, provocava

\footnotetext{
${ }^{7}$ Mestre em Sexologia - UGF/RJ. Professora auxiliar - VRPGPE/UNESA/RJ. Doutoranda em Direito Público e Social - UNESA. patriciacardoso2002@hotmail.com

2 Pós-Doutor em Ciência Política pelo Centro de Estudos de Cultura Contemporânea (CEDEC). Doutor em Direito pela UGF. Doutor em Letras Neolatinas -língua italiana/UFRJ Professor Permanente do PPGD/UNESA. Pesquisador do Núcleo de Estudos sobre Direito, Cidadania, Processo e Discurso/PPGD-UNESA. rafa.ioriofilho@gmail.com
} 


\section{VOZES $_{\text {\&IÁLORO }}^{\mid}$}

Itajaí, v. 18, n. 01, jan/jun 2019

sua esposa Hera, com seu comportamento infiel, levando-a a perseguir seus descendentes bastardos.

A Grécia antiga, berço dos grandes pensadores, institucionaliza a pederastia, o amor de um homem por um menino. Tannahill (1983) cita o relacionamento entre mestre e discípulo que tinha como finalidade o desenvolvimento moral e intelectual do jovem. Quanto mais atraente era o discípulo mais se acreditava na nobreza de sua mente privilegiando a responsabilidade do mestre em formá-lo. A consumação do relacionamento sexual entre mestres e pupilos foi objeto de discussão entre eruditos pela incerteza de sua veracidade, embora algumas pinturas de vasos atenienses retratassem o intercurso anal entre homens, sempre conduzido pelo mais velho (op. cit. p. 96)

Segundo Alexandrian (1993) a comédia grega antiga nasceu das festas anuais em honra de Dioniso, o deus do vinho ou da hybris (a embriaguez, o excesso). O sacrifício a Dioniso era seguido por procissões (falofórias) onde se entoavam cantos fálicos e se trocavam piadas obscenas, surgindo desses festejos os primeiros esboços da comédia antiga. Já Lisístrata de Aristófanes é a primeira obra-prima do erotismo antigo (op. cit, p.13), cuja linguagem rebuscada atenuava as obscenidades contidas no texto.

Prostitutas sagradas, poemas eróticos e objetos que imitavam o pênis, feitos sob encomenda, para a satisfação de damas solitárias e mulheres homossexuais (TANNAHILL, 1983), casas de banho, palácios com eunucos de bela constituição física, as vestimentas justas dos europeus do século XIV a XVI permeavam o mundo antigo de inegável eroticidade. No livro Cântico dos Cânticos do Antigo Testamento, a anatomia dos amantes é comparada ao esplendor palaciano: “(...) teu pescoço é semelhante à torre de Davi, constituída para depósito de armas” (Cant. 4, 4); “(...) suas pernas são colunas de alabastro erguidas sobre pedestais de ouro” (Cant.5, 15); “(...)Ora, eu sou um muro e meus seios são como torres...” (BÍBLIA SAGRADA, Cant. 8, 10).

O erotismo presente nas civilizações é amplamente difundindo pelo crescimento da indústria gráfica. Poetas e escritores se voltaram para a pornografia. Os manuais de sexo taoísta, segundo Tannahill, (op. cit. p. 348) inspiraram álbuns eróticos ilustrados e novelas pornográficas. O Marquês de Sade, ao publicar Justine ou Les Malheurs de la vertu em 1796, inspirou várias obras do gênero mesclando o sofrimento físico ao sexo em cenários bizarros. Em uma narrativa repugnante, segundo Alexandrian (1993), Justine sofre sevícias sexuais tão violentas que indignaram os amantes de livros eróticos.

A exploração do erotismo no mercado editorial vem atravessando os séculos. $\mathrm{O}$ que atualmente se transmite nos meios de comunicação pouco difere da iniciativa dos escritores do século XVIII (John Cleland - 1749/ Andrea de Nerciat - 1755/ Mirabeau 1782 / Sade - 1796) que viram na necessidade da afirmação sexual masculina uma oportunidade de mercado.

O masoquismo é definido pela primeira vez em fins do século XX por Richard Von Krafft-Ebing, psiquiatra austríaco, em seu estudo do comportamento sexual patológico 


\section{VOZES $_{\text {\&IÁLORO }}^{\mid}$}

Itajaí, v. 18, n. 01, jan/jun 2019

intitulado Psychophathia Sexualis (1886). Krafft-Ebing, baseando-se no tipo de prazer sexual com a aplicação da dor inspirada por Sade, conceitua o prazer de ser humilhado ou ferido em decorrência das novelas de Sacher-Masoch surgidas em 1870, "versando sobre homens precisando de mulheres que lhes infligissem dor” (op. cit. p. 415).

Para Freud (1989), a particularidade mais notável dessa perversão reside na existência das formas ativa e passiva numa mesma pessoa, ou seja, quem sente prazer em provocar dor no outro na relação sexual pode experimentar o gozo advindo de qualquer dor que possa obter das relações sexuais.

O erotismo está presente na história literária seguindo as tendências dos gêneros que marcaram as épocas como o Medievalismo, o Renascimento, o Romantismo, o Realismo e o Surrealismo. Foi a partir da Idade Média que a Inglaterra e a França influenciaram as outras nações na produção de obras do gênero (ALEXANDRIAN, 1993).

No século XIX, o Ocidente expande seus conhecimentos $\mathrm{cm}$ torno do erotismo ao descobrir a erotologia oriental. A tradução em 1850 de Le Jardin parfumé, um manuscrito árabe do século XVI, pelo Barão de R., capitão do estado maior em Argel, permitiu à França o conhecimento de posições sexuais, afrodisíacos, anedotas sobre o adultério feminino e conselhos para facilitar o coito entre pessoas de diferente constituição física (op. cit. p. 252). A obra, originalmente escrita no ano de 925 pelo xeque Nefzaoui de Tunis, foi então incrementada por desenhos na ocasião da reprodução em trinta e cinco exemplares, no ano de 1876.

Outra descoberta significativa ocorreu em 1883, The Kama Sutra of Vatsyayana, impresso em Londres por um colecionador inglês, Sir Henry Spencer Ashbee, uma extraordinária demonstração da arte de amar hindu. O autor classificou e denominou tipos de beijos, carícias leves ou intensas, dentadas amorosas, fases do intercurso oral, tratou sobre as dimensões sexuais (a adaptação do pênis à vagina), mas a notoriedade da obra está relacionada às sugestões de posições do intercurso, um verdadeiro espetáculo contorcionista (TANNAHILL, 1980).

Vale ressaltar a contribuição feminina no gênero erótico, que eclodiu na França ao final do século XIX:

A pioneira Marquesa de Mannoury (1880), Marie-Amélie Chartroule (1877), Rachilde - pseudônimo de Marguerite Aimery - (1889), Natalie Clifford-Barney (1910), Renée Vivien (1904), Colette (1904), Lucie Delarue- Mardrus (rival literária de Colette) e Renée Dunan (1922), a maioria delas amantes do safismo.

Sobre Renée Dunan Alexandrian (1993) escreveu:

Apesar de ter publicado quase cinquenta livros (...) não se encontra nenhuma informação sobre Renée Dunan, falecida em 1936, em grossos

\footnotetext{
${ }^{3}$ Safo, a primeira poetisa erótica da Antiguidade. Homossexual, escrevia poemas dedicados às amantes.
} 


\section{VOZES $_{\text {\&IÁLORO }}^{\mid}$}

Itajaí, v. 18, n. 01, jan/jun 2019

dicionários de literatura contemporânea onde figuram autores menores, menos dignos de serem impostos à posteridade. Está aí uma prova do ostracismo lamentável que atinge as mulheres que escrevem francamente sobre o sexo: tem-se a impressão de que elas perturbam as prevenções masculinas (ALEXANDRIAN, 1993, p.305).

Naquela ocasião, a indústria editorial francesa foi surpreendida pela censura, que punia o atentado ao pudor ou aos bons costumes, embora para os editores isso representasse uma luta de liberdade total de expressão. O decreto-lei de 29 de junho de 1939 levou várias obras à mira do juiz de instrução, que determinava a improcedência da acusação ou o encaminhamento da respectiva publicação ao tribunal correlacional, podendo ser submetido à revisão de julgamento no tribunal de apelação (op. cit. p. 428).

No universo erótico há uma linha tênue entre o permitido e o proibido. A repressão presente na sociedade, mantida por convenções sociais ou ideologias religiosas, favorece o desejo de transgressão. O proibido exerce fascínio nos indivíduos levando-os a transgredir ou não certas normas sociais. O que é difundido como norma de conduta condenável pode ser também experimentado no mundo erótico, o que torna possível a realização de desejos e obtenção de prazer (PARKER, 1991). Viabiliza a realização de práticas sexuais em um universo simbólico, distanciando-se da classificação de imoralidade. É estruturada em um universo alternativo (op. cit., p. 18) que ganha forma concreta nas páginas dos livros e revistas por meio de ilustrações, narrativas e fotografias formando a ideologia do erotismo.

O sucesso das revistas masculinas que surgiram ao final do século XIX é uma representação desse universo simbólico, que se popularizou ainda mais pela utilização de modelos nus. Inicialmente essas publicações revelavam a intimidade vivenciada nos bordéis com ironia ou humor de forma enrustida, razão pela qual eram chamadas de "galantes".

De acordo com o livro A Revista no Brasil (2000), uma coletânea realizada pela Editora Abril sobre os periódicos brasileiros, o Rio $N u(1898$ - 1916) foi a primeira revista do gênero a fazer sucesso no Brasil, pois "começou como tabloide semanal, mas em treze meses inchou de quatro para oito páginas e passou a dar "duas por semana", conforme registrou num bem-humorado editorial” (op. cit. p. 183). A partir de 1922, outras surgiram e se consolidaram no mercado nacional mesmo com todos os vetos da censura.

Ao final da década de 1950, publicações pornográficas também conhecidas como “catecismos” eram notórias na cultura masculina. Adquiridas clandestinamente, passavam de pai para filho, servindo como manuais de iniciação sexual. Essas "revistinhas de sacanagem” como também eram conhecidas, possuíam uma variedade de histórias eróticas (PARKER, 1991) ilustradas por desenhos explícitos. As mais populares eram as de Carlos Zéfiro, pseudônimo de Alcides Aguiar Caminha, cuja identidade somente foi revelada em 1991 numa reportagem de Juca Kfouri na Playboy (A REVISTA NO BRASIL, 2000). 


\section{VOZES $_{\text {\&IÁLORO }}^{\mid}$}

Itajaí, v. 18, n. 01, jan/jun 2019

Alcides era um pacato funcionário público, razão pela qual temia ser descoberto, o que poderia custar seu emprego. As histórias pornôs de Zéfiro, autor de quase 1000 brochuras vendidas clandestinamente nas bancas de jornal, desafiou a ditadura militar.

Zéfiro parou de desenhar em meados de 1968 devido a perseguição da ditadura e a concorrência desleal das revistas dinamarquesas, que aqui chegaram trazendo fotos de sexo feitas sem nenhuma censura.

Como a repressão era intensa, os jornaleiros tinham que disfarçar os catecismos, vendendo-os dentro de outras revistas. Fala-se até que os jornaleiros foram os que mais ganharam, pois o leitor era obrigado a comprar duas revistas. $\mathrm{O}$ que não se falava em casa, lia-se em Carlos Zéfiro. Detecta-se em certo exagero a se ver em Carlos Zéfiro um sentido pedagógico ou um papel de ideólogo que o autor jamais pensou ter.

Dentro de uma sofisticação editorial, Fairplay revela a modernização da revista masculina, seguida por Ele Ela. Ambas sofreram intervenções da censura por traduzirem a nudez feminina de forma mais ousada

Já Ele Ela abordava os temas relacionados à sexualidade sem rodeios, mostrando a nudez feminina. Seu primeiro exemplar oferecia aos leitores um caderno sobre sexo.

Apesar dos vetos da censura, sua tiragem foi crescendo alcançando $400 \mathrm{mil}$ exemplares em 1980 (A REVISTA NO BRASIL, 2000).

Em 1987, Playboy tornou-se a publicação mensal de maior circulação no país, combinando belas mulheres e jornalismo de qualidade. Por causa da censura, não podia publicar mais que um seio por página e somente a partir de 1980 o nu frontal pode ser inserido nas revistas masculinas.

A produção de livros ou revistas de teor erótico, controversos ou não, aumentou o espaço da intimidade, revelando um homem mais verdadeiro "que pode ser surpreendido no espaço privado e íntimo, onde as relações de afeto são naturais em oposição aos terríveis interesses do mundo material e social” (LÁZARO, 1996). Esse retorno à interioridade transforma a abordagem do prazer numa excelente oportunidade de mercado para a literatura e o comércio (op. cit. p. 194). A sexualidade, então, se converte em um objeto de discussão intensamente difundido por sua relevância na esfera social.

Atualmente, a diversão erótica está mais acessível. O computador oferece vários mecanismos como sites, aplicativos e jogos, permitindo um maior acesso ao material erótico. Há ainda o mercado dos filmes eróticos e os diversos produtos disponíveis nos sex shops.

Apesar das facilidades modernas, Playboy (Ed. Abril) ainda se sustentou no mercado editorial de forma significativa, confirmando a importância do processo de segmentação, capaz de atribuir características bem definidas a um determinado público.

Sua última edição se deu em dezembro de 2017.

A temática do prazer, vinculada ou não à lógica da mercadoria, ainda que atrelada aos discursos da cultura de massa e da publicidade, representa uma libertação dos limites 


\section{VOZES! \\ ¿DIÁl DCo}

Itajaí, v. 18, n. 01, jan/jun 2019

impostos pela repressão, transformando-se em algo que exige maiores reflexões, já que atualmente vivemos um redimensionamento da sexualidade, anteriormente empobrecida pela clássica concepção de sexo vinculado à reprodução.

Como afirma Mcluhan (2001), a mensagem de qualquer meio ou tecnologia é a mudança de escala, cadência ou padrão que esse meio ou tecnologia introduz nas coisas humanas. Se os personagens das publicações eróticas são indecentes, sádicos ou fora do padrão de normalidade, abrem espaço à discussão ética da sexualidade.

\section{Mulher e mercado: a sedução da publicidade}

A linguagem publicitária gera uma cultura própria na sociedade de consumo ao conduzir os consumidores a um universo simbólico, lançando mão das aspirações e desejos de um determinado público para identificá-lo a um produto.

A mensagem publicitária exibe um mundo perfeito, um misto de brilho, cor, charme e sedução. Como afirma Carvalho (1998), não se distancia completamente do mundo real, mas concilia o princípio do prazer com o da realidade, indicando o que deve ser usado ou comprado.

Para Ladeira (1977) o publicitário "que externa o já descoberto e o já determinado, oferece ao consumidor um mundo fechado. Assim, em lugar de provocar desenvolvimento de vida subjetiva, o publicitário reduz vivências do receptor, levando-o a uma única atitude: o consumo”. Daí a importância da criação de atmosferas insólitas agradáveis, onde geralmente as coisas acontecem em termos de resultados felizes, atraentes e otimistas para convencer e seduzir o receptor.

Carvalho (1998) diferencia propaganda e publicidade, relacionando a primeira aos valores éticos e sociais (propaganda institucional, religiosa, ideológica) enquanto a publicidade explora o universo dos desejos, não deixando transparecer suas verdadeiras intenções, ideias e sentimentos. Segundo esta autora, a publicidade utiliza os seguintes recursos:

- a ordem (fazendo agir) - "Beba Coca-Cola";

- a persuasão (fazendo crer) - Só Omo lava mais branco”; ou

- a sedução (buscando o prazer) - "Se algum desconhecido lhe oferecer flores, isto é Impulse” .

No dizer de Marcondes Filho (1992), a publicidade vende a aparência de felicidade, o mundo quase real, a ilusão do desfrute e do prazer, o alívio por meio do consumo. Cria mecanismos fora da esfera econômica gerando no receptor a necessidade de adquirir mercadorias. Em sua opinião, o que está em evidência não é o consumo imediato ou o valor de uso das mercadorias, mas a satisfação substituta: “compre um carro e você 


\section{VOZES $_{\text {\&IÁLORO }}^{\mid}$}

Itajaí, v. 18, n. 01, jan/jun 2019

pertencerá a um mundo exclusivo de pessoas especiais”, “ para quem sabe o que quer”, etc. Para ele, não se vende o produto, mas os elementos ideológicos de diferenciação do mundo capitalista.

O termo publicidade (do francês publicité) surgiu na França por volta de 1820 (CARVALHO, 1994) significando o que é do julgamento do público. O "reclame”, como inicialmente era chamado, se afirmou a partir do século XIX com a evolução da interação entre as esferas pública e privada face às mudanças ocorridas na sociedade, evidenciando “áreas compartimentalizadas como o trabalho, o lazer e a convivialidade" (CARVALHO, 1994) e, no século XIX, o público leitor passou a ser orientado para o consumo, intensificando a publicidade comercial.

Tal processo interativo entre as duas esferas propiciou o surgimento de novas práticas retratadas no texto impresso, enriquecido pela modernização dos recursos tipográficos. Esse novo estilo de vida que exigiu da mulher a reestruturação de sua esfera privada em decorrência de uma participação maior na vida pública, suscitou uma imprensa interessada em mediar os interesses privados desse público. Surge, portanto, a imprensa feminina, especificamente elaborada e pensada para mulheres:

Imprensa feminina é um conceito definitivamente sexuado: o sexo de seu público faz parte de sua natureza. Desde que surgiu no mundo ocidental, no fim do século XVII, já trouxe a destinação às mulheres no próprio título do jornal - Lady's Mercury - prática a persistir até hoje. A começar do nome, a maioria das publicações, programas de rádio e TV femininos indicam claramente para quem se dirigem (BUITONI, 1990).

Esse conceito de imprensa especificamente dirigida a um público não existia no passado. Os jornais eram destinados às pessoas de ambos os sexos. Buitoni (Buitoni, 1990b) afirma que não havia uma imprensa masculina, lembrando que "público" é uma conceituação moderna, ligada quase sempre a várias camadas sociais. A imprensa feminina focalizou de imediato a mulher e a masculina surgiu bem depois em decorrência da segmentação do mercado.

Outra característica da imprensa feminina é sua ligação com o novo. A novidade, os modismos, a febre do mundo fashion impregnam essas revistas, que veiculam "o que há de mais moderno, atual”, seja em termos de moda, comportamento, beleza, criando um clima de descoberta e conexão aos últimos acontecimentos.

Nesse sentido, coube ao periodismo a prefiguração de modelos femininos reiterando a tradicional postura de rainha do lar, mas abrindo um leque de condutas alternativas, em que se projetou a mulher emancipada, educadora, esportista, saudável, moderna e, por que não, a sufragista e feminista. Em outras palavras, prefigurava-se a mulher que interessava ao mercado, identificada como cliente em potencial, capaz 


\section{VOZES $_{\text {\&IÁLORO }}^{\mid}$}

Itajaí, v. 18, n. 01, jan/jun 2019

de influenciar as decisões de família, vista como um ser em expansão (MARTINS, 2001).

A imprensa feminina, por utilizar informações de fontes variadas, permanentemente conta com o auxílio de colaboradores e especialistas de diversas áreas, complementando o trabalho dos jornalistas.

Tais publicações precisam socorrer-se do imprescindível conhecimento de pessoas que não fazem parte da estrutura editorial comum. A especialização da ciência contribuiu ainda mais para aumentar a presença desses profissionais, principalmente em assuntos relacionados à saúde (BUITONI, 1990).

As revistas femininas, embora pressionadas pelos propósitos comerciais e criticadas por darem à mulher uma imagem estereotipada - mãe, esposa, dona-de-casa, objeto sexual - são confeccionadas em função desse público e, por essa razão, precisam do estereótipo e da publicidade para sobreviver no mercado editorial.

Não se pode desprezar sua relação com o jornalismo de serviço, seja divulgando receitas práticas ou roupas em promoção para facilitar a vida cotidiana, ou apresentando pontos de vistas variados nos artigos sobre saúde, educação sexual, economia e feminismo.

Pela amplitude de sua área de abrangência, pode-se dizer que esta imprensa é interdisciplinar: aborda uma variedade de assuntos interligados em torno da figura feminina. Praticamente qualquer assunto pode ser veiculado, sendo, portanto, uma imprensa eclética, "do calo no pé a matérias sobre ecologia; da jardinagem à violência contra as mulheres, tudo pode ser colocado em pauta” (BUITONI, 1990).

No que refere à sexualidade, houve um avanço significativo. Atualmente, o sexoprazer é amplamente discutido, não só no aspecto positivo e lúdico. Veicula-se também os fatores que interferem de forma negativa como disfunções sexuais, crenças errôneas em relação à sexualidade, traumas de infância e a dificuldade das mulheres em revelar ao parceiro sua insatisfação sexual.

Com a participação dos especialistas nos diversos campos de atuação (biopsicossocial), as revistas se esforçam no esclarecimento das dúvidas das leitoras, respaldadas pelo conhecimento de seus colaboradores. Assim sendo, fornecem uma visão ampla do ser humano que interage com o seu mundo biológico, psicológico e sociocultural.

\section{A mulher consumidora}

Em decorrência do desenvolvimento industrial, da urbanização e do surgimento da classe média, novas exigências se estabelecem na sociedade moderna, transformando a casa em um cenário de utilidade e praticidade. Isto proporcionou, nos anos 50, o crescimento 


\section{VOZES $_{\text {\&IÁLORO }}^{\mid}$}

Itajaí, v. 18, n. 01, jan/jun 2019

das indústrias relacionadas à mulher (cosméticos, moda, culinária), estabelecendo a conexão consumo/imprensa feminina (BUITONI, 1990; CASTRO; 1992).

A sociedade de consumo se utiliza de uma imagem de mulher socialmente construída pelo patriarcado. Para Carvalho (1998), essa imagem revela a domesticidade feminina pela visão da mulher como protetora/provedora das necessidades da família e da casa, não pelo aspecto econômico para a manutenção do lar, mas por sua função de sair de casa para comprar.

A estrutura do feminino está ancorada na relação ter para ser. Se essa imagem foi construída no sentido de proteger ou prover a família e a casa, para Ser é preciso marcar presença nas prateleiras dos supermercados, dando sobrevida às leis de consumo.

Com o aperfeiçoamento da tecnologia gráfica promovendo uma visualização maior de detalhes pela quantidade de fotos e cores, a revista tornou-se a mídia mais adequada para a moda, dando destaque, movimento e fantasia às modelos fotografadas em cenários especiais. Os anúncios e campanhas publicitárias voltadas ao público feminino exploram a aparência e a vaidade como fator de sucesso das mulheres e conquista da felicidade, sobretudo como fórmula de sedução.

Embora haja na sociedade vários tipos definidos de mulher, a publicidade dirigida ao público feminino tem utilizado a exigência da perfeição para atingir mulheres de todos os segmentos. A mulher tem que ser moderna, antenada, mãe perfeita, excelente dona-decasa, excelente profissional, esposa perfeita e, obviamente, excelente amante.

A mulher liberada como receptor alvo é retratada tanto nos textos como nas fotos dos anúncios de moda com atitude mais liberal e sedutora, realizando fantasias sexuais e dominando os homens. Os exemplos a seguir ilustram bem essa característica da imprensa feminina da atualidade.

Nota-se aqui a identificação com o perfil "liberada", tanto na atitude da modelo como no texto publicitário, que explica o que vem a ser o livre acesso. A roupa não deve complicar a vida das mulheres, principalmente a vida íntima.

Como diz o texto "roupa para namorar, além de sexy não pode exigir nenhum esforço na hora de tirar". Daí o conselho "Escolha saias, vestidos e tops que tenham amarrações, elástico ou simplesmente o decote que facilite o sobe-e-desce! Ele vai adorar. ” Em suma, a mulher deve estar preparada para situações inusitadas e livrar-se de uma roupa não pode ser um inconveniente.

As roupas aqui prometem momentos inesquecíveis. Como diz a revista: "Você vai seduzir como nunca, toda coberta de dourado".

Essa afirmação atribui às roupas um poder mágico de sedução. Vestir um top de metal com uma saia é um "mix no qual você pode apostar" e quem sabe, seduzir dois

homens ao mesmo tempo e realizar a fantasia da maioria das mulheres, um mix erótico. 


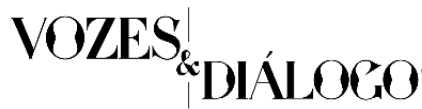

Itajaí, v. 18, n. 01, jan/jun 2019

Tudo pode acontecer a três ao usar a calça "bem colada" com a frente única de lurex. Novamente a lógica da mercadoria mexendo com o imaginário feminino.

O surgimento do homem-objeto é uma tendência que aos poucos vai ocupando

espaço na mídia. Há uma ambivalência nos discursos, pois oferecem às mulheres um número considerável de fórmulas para agradar o parceiro e mantê-lo ao seu lado, sendo, portanto, um objeto de consumo desse homem. Ao mesmo tempo, as revistas as estimulam a ir a caça, logo eles também se tornam um objeto de consumo.

Embora nos últimos anos as mulheres passassem a pensar mais a respeito da própria sexualidade, a busca pela perfeição estética acaba inibindo seu exercício. $\mathrm{Na}$ verdade, sentir-se mais sedutora é viver em sintonia com o próprio corpo e os sentidos.

Ladeira (2001) afirma que, ao contrário das décadas passadas quando a moda estava estreitamente associada a uma camada específica, na contemporaneidade essa camada específica já não existe mais e a reprodução dos "padrões estéticos”, e em especial a moda, é consumida em massa em todos os níveis culturais e sociais.

Os veículos femininos também são elaborados em torno de um segmento, portanto trabalham de acordo com o perfil desse público fazendo uso do estereótipo e da publicidade.

Em termos de consumo, algumas mudanças ocorreram desde que as mulheres intensificaram seu poder de compra. Não só no Brasil como no mundo inteiro, as mulheres possuem grande influência na decisão de compra da família, além de serem responsáveis pela maior parte do consumo no comércio.

Com menos tempo disponível e conquistando o mercado de trabalho, as mulheres mais facilmente vêm se tornando líderes de consumo. Segundo a agência Eva de Comunicação, as mulheres influenciam 80\% das compras de automóveis, 99\% das compras de produtos de higiene e limpeza e $90 \%$ das compras de alimentos.

O Instituto Nielsen e F/Nazca apresenta da seguinte forma o perfil da mulher consumidora:

- Busca produtos em ofertas e promoções

- Quer saber detalhes sobre os produtos

- Gosta de ler anúncios publicitários

- Preocupa-se com segurança e bem-estar

- É fiel a marcas

A imprensa feminina trata da vida "o vestir", "o comer”, "o morar", "o amar" e pode influir mais cotidianamente na vida das pessoas que um poderoso jornal diário, apesar das restrições acarretadas pela estética da utilidade e o consumismo. (Buitoni, 1990e). 


\section{VOZES \\ ¿DIÁl DCo}

Itajaí, v. 18, n. 01, jan/jun 2019

Dentro das regras capitalistas, o desejo das mulheres foi transformado em mercadorias pela imprensa feminina, mas esta também exerce seu papel pedagógico e conscientizador.

Sobre a construção do perfil feminino como consumidora estimulada para a aquisição de produtos no mercado, Martins (2001) comenta que, mesmo em revistas de temáticas consideradas masculinas, encontrava-se a seção "o cantinho da mulher”, ou "figurino da moda" e mesmo o irresistível "folhetim".

\section{Considerações finais}

Refletindo os modelos socialmente construídos e reforçados dentro da lógica do mercado, a imprensa feminina expõe as diversas condutas e posturas em voga: o papel de mãe, a ousadia da mulher sexualmente liberada, a determinação das mulheres financeiramente independentes, as que se destacam na ciência ou na política, as que discutem os novos rumos do feminismo, as que criam a moda e as que fazem imprensa.

Assim como a vida, a imprensa feminina é múltipla e contraditória, um campo vasto, excitante e em constante movimento. A despeito de pouco contribuir para a modificação da estrutura sociocultural vigente, ao reforçarem estereótipos de gênero e preconceitos raciais, as revistas femininas evoluíram muito ao priorizarem a preocupação de suas leitoras quanto à forma de encarar a sexualidade.

Todo o processo de conquistas femininas do qual as revistas também participaram poderão gerar uma mudança de postura desses meios. As revistas podem e devem contribuir para a redução dos limites impostos pelo patriarcado, não relegando à mulher o tradicional papel de objeto de prazer (MARCONDES FILHO, 1992) para a satisfação e manutenção do homem, mas destacando-a como pessoa em busca da realização afetiva e sexual.

Pode-se afirmar que a abordagem da sexualidade nas revistas femininas é uma iniciativa que se ajusta ao conceito de educomunicação. Essas mídias são pioneiras em um campo de interação social utilizando os recursos da informação como meio de expressão e produção cultural.

A relevância social desse processo é bastante significativa, visto terem esses meios iniciado essa construção em um universo caracterizado pela falta de informação e formação no que diz respeito à sexualidade.

\section{Referências bibliográficas}

ALEXANDRIAN. História da literatura erótica. Rio de Janeiro, Rocco, 1993.

A REVISTA NO BRASIL. SP: Abril, 2000. 


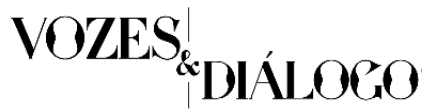

Itajaí, v. 18, n. 01, jan/jun 2019

BÍBLIA SAGRADA. $119^{2}$ ed. SP: Ave Maria, 1998.

BUITONI, Dulcília Schroeder. Imprensa Feminina. 2a ed. SP: Ática, 1990.

CARVALHO, Katia de. A cidade das revistas. Imprensa Feminina no Rio de Janeiro anos 20. Rio de Janeiro. Centro de Filosofia e Ciências Humanas da Universidade Federal do Rio de Janeiro, 1994. Tese de Doutoramento.

CARVALHO, Nelly de. Publicidade, a linguagem da sedução. SP: Ática, 1998.

O GLOBO DIGITAL. Catecismos de Carlos Zéfiro driblaram a repressão sexual..

(on line) Disponível em: https://acervo.oglobo.globo.com/em-destaque/catecismos-decarlos-zefiro-driblaram-repressao-sexual-dos-anos-50-aos-70-21546395. Acesso em 23 de dezembro de 2018.

LADEIRA, Adriana L.S. A influência da mídia e os estereótipos corporais. Rio de Janeiro. Escola de Comunicação da Universidade Federal do Rio de Janeiro, 2001. Dissertação de Mestrado.

LÁZARO, André. Amor: do mito ao mercado. Petrópolis, RJ: Vozes, 1996.

MARCONDES FILHO, Ciro. Quem manipula Quem? Poder e Massas na indústria da cultura e da comunicação no Brasil. $5^{\text {a }}$ ed. Petrópolis, RJ: Vozes, 1992.

MARTINS, Ana Luiza. Revistas em revista. Imprensa e práticas culturais em tempos de República. São Paulo: Edusp, 2001.

MCLUHAN, Marshall. Os meios de comunicação como extensões do homem.11" ed. São Paulo: Cultrix, 2001.

PARKER, Richard G. Corpos, Prazeres e Paixões. A Cultura Sexual no Brasil Contemporâneo. SP: Best Seller, 1991.

TANNAHILL, Reay. O sexo na história. Rio de Janeiro, Ed. Francisco Alves, 1983. 